\title{
Analysis of Farmers' Stated Risk Using Lotteries and Their Perceptions of Climate Change in the Northwest of Mexico
}

\author{
Miguel Angel Orduño Torres ${ }^{1, * \mathbb{D}}$, Zein Kallas ${ }^{2} \mathbb{D}$ and Selene Ivette Ornelas Herrera ${ }^{3}$ \\ 1 Institute for Research in Sustainability Science and Technology (IS-UPC), Polytechnic University of \\ Catalonia, 08034 Barcelona, Spain \\ 2 Center for Research in Agrofood Economy and Development (CREDA-UPC-IRTA), \\ Polytechnic University of Catalonia, Institute of Agrifood Research and Technology, 08860 Castelldefels, \\ Spain; zein.kallas@upc.edu \\ 3 Faculty of Mathematics and Statistics (FME-UPC), Polytechnic University of Catalonia, 08028 Barcelona, \\ Spain; selene.ivette.ornelas@upc.edu \\ * Correspondence: miguel.angel.orduno@upc.edu; Tel.: +34-651-78-76-31
}

Received: 30 October 2018; Accepted: 18 December 2018; Published: 21 December 2018

\begin{abstract}
Risk attitudes are relevant factors affecting production, management and investment decisions at the farm level. They are key factors related to farmers' attitudes towards the environment and climate change. Several methodological approaches, which were considered to be preferable for measuring the level of risk of an economic agent, ranging from highly risk-tolerant to highly risk-averse attitudes, are available. The Multiple Price List (MPL) method is one of the stated approaches that is gaining relevance. In this study, we apply the MPL and relate the risk outcomes to farmers' socio-economic characteristics and their perceptions of the environment and climate change. Data were collected using a face-to-face survey, carried out with a group of 370 farmers of an irrigation district, located in the northwest of Mexico. The results showed a risk level of about 0.32, according to the Constant Relative Risk Aversion (CRRA) coefficient, locating farmers of the region in a risk-averse group. The heterogeneity analysis showed that the socioeconomic factors and the perceptions of climate change are related to the farmers' stated risk level. Farmers who are young women, with a tendency to use public support for structural investment, were shown to be risk-tolerant. Farmers considered floods, hail, diseases, pests, and weed growth incidences to be the most frequent weather patterns in the region.
\end{abstract}

Keywords: risk attitude; farmers; multiple price list; lotteries and climate change

\section{Introduction and Objectives}

Climate change is one of the greatest challenges of our times. This phenomenon refers to the long-term variation of the climate generated by natural causes or human actions that distort climatic parameters, such as temperature and precipitation [1]. The way in which weather patterns occur represents a risk, especially for agricultural production due to floods, storms, droughts and hail [2]. Climate is the most significant component in the practice of agricultural activities and is continuously affecting farmers' decisions, mainly by increasing the uncertainty of the production [3].

Farmers' perceptions of climate change are increasingly playing an important role in agricultural output and farmers' decisions at the farm level [4-6]. The perceptions are a set of understandings and sensitivities, integrating an objective and subjective vision about the environment, that allows for the conceptualization of beliefs, values and norms and determines if attitudes are positive or negative [7]. These perceptions are multidimensional and are mainly related to farmers' risk attitudes, opinions and 
their socio-economic characteristics $[8,9]$. They may have a direct impact on the development of public policy programs regarding the agricultural production sector, as well as on farmers' actions related to energy consumption (type and quantity of energy used in machinery and equipment) [10-12].

In fact, several determinants can be related to the farmer's risk attitude, which in turn may affect his/her decision at the farm level. The socioeconomic characteristics of farmers (such as age, sex, percentage of income from agriculture, agricultural experience, etc.) are relevant determinants [13]. The farm descriptors (land tenure regime, agricultural subsidies, size, crop diversity and type, rainfed or irrigation land, harvest type, etc.) may also be associated with the determination of risk attitudes [14,15]. Farmers' perceptions of weather patterns are also significant factors affecting their farming management, crop rotation and investment decisions [16]. Their opinions and attitudes concerning the environment may also directly or indirectly impact their decisions, with a certain level of uncertainty [17].

In this context, the main objective of this paper is to analyze the farmers' stated risk attitudes in an agricultural region in Mexico, using the Multiple Price Lists (MPL) method, known as "Lotteries", as an alternative method that belongs to the expected utility risk elicitation approach. We also seek to analyze the heterogeneity of the risk attitude level with farmers' opinions concerning the environment and perceptions of climate change. The heterogeneity analysis will also be conducted by analyzing the risk attitudes in relation to the abovementioned farms and farmers' characteristics, perception, attitudes and opinions. Farmers' attitudes and sensibility concerning the environment will be also included. Finally, we will identify attitude patterns, which allow for the differentiation of groups of producers whose characteristics aid in understanding the decisions that they make regarding their activities in order to inform policy makers on farmers' preferences.

This paper contributes to the existing literature on farmers' risk attitudes by contributing new insight, using the MPL method in Mexico. Reviewing the existing literature, there seems to be very scarce or no information regarding the measurement of the risk aversion level of farmers' stated risk in Mexico using the MPL. This paper contributes to the verification of the effectiveness and reliability of this technical risk analysis, with a specific empirical application, and can be easily understood by farmers, without the need for specific prior knowledge of the interviewees. It also offers the opportunity to compare our results with other agricultural systems with similar or different management practices and crops.

\section{Background}

The specific study site is identified as irrigation district DR076, which is located in the Carrizo Valley in the state of Sinaloa in Northwestern Mexico, and is eight meters above sea level (Figure 1). The extension of the irrigation district DR076 is approximately 70,172 ha and has 24,017 inhabitants, distributed in 27 localities, with a Gross Domestic Production (GDP) of \$143,052 (\$= Mexican Pesos $(\mathrm{MXN}) ; \$ 100(\mathrm{MXN})=4.89 \mathrm{USD})$ [18]. Its main economic activity is based on agricultural and animal production, with land characteristics that are very appropriate for crop farming. The irrigation district DR076 is considered one of the most important regions for crop production, which are mainly cereals, such as wheat, with $76 \%$ of the total Agricultural Area Used (UAA), and corn, with 8\% [19]. The main irrigation system is by gravity, where water resources are obtained from the "Rio Fuerte" river and the water dam, called "Josefa Ortiz de Dominguez," with a water volume capacity of one billion and 227 million $\mathrm{m}^{3}$.

In the northwestern region of Mexico, the increase of the temperature and the decrease of the annual precipitation is a generalized trend [20]. In the particular case of the Irrigation District DR076, the atypical climatic conditions have been very extreme in recent years (in particular, in 2013), where the lack of rain, low temperature and strong droughts have been more frequent, causing considerable output losses [21]. In 2011, frost weather led to a total loss of the corn yield [22]. In fact, the effect of climate change is closely related to a reduction in economic growth, making it harder to reduce poverty and ensure the food security of local and marginal agricultural communities. [23]. 


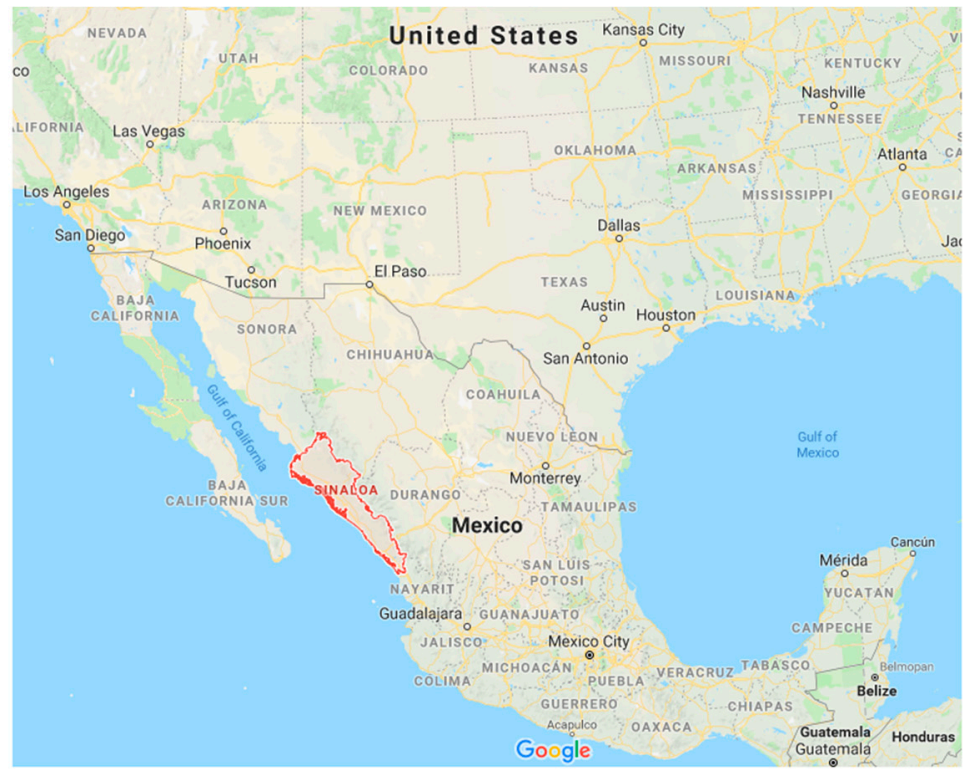

1) Irrigation district 076 , Sinaloa, Mexico

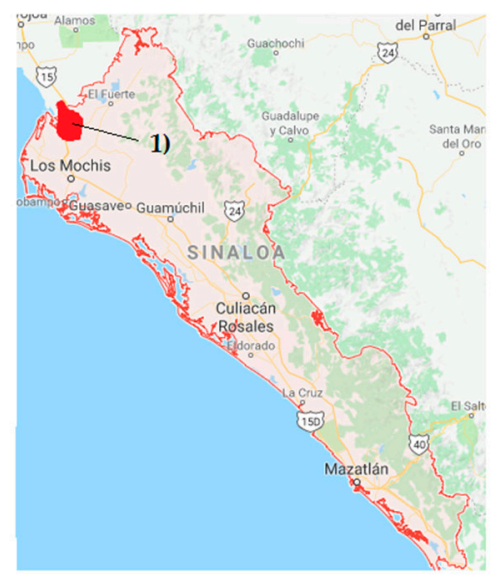

Figure 1. Location of the study area: Irrigation District DR076, Sinaloa Mexico [24].

The risk attitude is an aspect related to the behavior of the human being, especially that affecting their economic decisions. According to the neoclassical economic theory, in general terms, individuals are risk-averse, exhibit a low risk tolerance and tend toward profit maximization $[25,26]$. Risk attitude is individual-specific behavior that affects personal and professional decisions, in particular, investment options, such as the amount and periodicity in any economic activity.

To analyze risk attitudes, several methodological approaches are available that are developed and implemented with a great emphasis on those aspects associated with economic activities, such as agriculture. The stated risk elicitation is one of the most widely used approaches, in which individuals are asked in a survey about their risk behavior. This approach can rely on the multi-affirmation method, which often includes the self-assessment of risk attitude. It can also rely on methods that are based on empirical data analysis and on the expected utility theory. The Expected Utility Theory was initially introduced by Daniel Bernoulli in 1738. According to this theory, the analysis of decisions under uncertainty, individuals choose the option that provides the highest expected utility, corresponding to the sum of the products of probability and utility over all possible outcomes. John von Neumann and Oskar Morgenstern contributed to the original conception of the theory in 1944 by explaining the decision under uncertainty that minimizes the risk of an election, and this was followed in this research $[27,28]$. This conception is based on several conditions that are related to rational equability, in which agents rationally assess the odds of the different scenarios to be evaluated. In this context, the decisions taken under risk are analyzed among different alternatives, assuming that the decisions have an order of preference and are defined based on a probability distribution for a certain number of affirmations or sentences [29].

However, the risk attitude cannot be only measured directly based on the expected utility, $U(X)$, because it also depends on the strength of the preference ("not to risk"), represented by $V(X)$ [30-32], where $X$ corresponds to the income (a specific amount), in order to obtain a more accurate measure of the risk attitude, which is known as a "True Equivalent" measure [33]. True Equivalent is a certain amount of money, and a person is indifferent to whether there is a secure payment or uncertain payments of a certain investment [34]. This measure was applied in this study.

\section{Theoretical Framework of the Stated Risk Analysis}

As previously noted, risk is a key variable of decisions under uncertainty. Each involved individual or decision-maker has a different attitude towards risk; hence, the degree of risk aversion needs to be quantified in order to identify differences and similarities. There are numerous methods 
that are used successfully in economics and agricultural management to measure stated attitudes concerning risk based on surveys of the individuals involved in economic activities. These methods could be divided into: (i) Methods based on an attitudinal scale, with multiple affirmations or statements, (ii) methods based on the theory of expected utility, and (iii) methods that involve a combination of the previous ones.

The attitudinal scale methods are constructed based on the score assigned to multiple statements using a certain scale of values [35]. Using these methods, the risk attitude is considered a latent construct (a dependent variable) that is not directly observable, but can be estimated through other explanatory variables that are related to the statements proposed by different researchers, depending on the topic of study.

The empirical methods based on the economic theory of expected utility $[36,37]$ estimate an indicator of risk aversion as a function of probabilities in a non-parametric framework, since it is not a function of the utility that is supposed to govern the behavior of individuals. The following is a brief description of the main applications measuring the stated risk level in agriculture, based on surveys and interviews:

- Bardhan's attitudinal scale of five points on dairy farmers in India, which identifies the most relevant sources of risk according to farmers' perceptions and attitudes [38], based on 31 statements related to the social and psychological attributes of each farmer [39].

- Risk attitude measuring instrument RAMI of Fausti and Gillespie, applied to cattle producers in the United States [40]. The instrument was made up of five questions, and the last three were defined according to the certainty equivalence framework associated with the expected utility model.

- Scale of the measurement of risk attitudes, based on three factors of Allub's scale concerning the hypothesis that risk aversion and income diversification are the factors that influenced the farmers' decisions in a case study in Argentina [41]. It considered that risk aversion is determined by three factors: The socio-economic status of the farmer, the degree of involvement or participation in the rural development program, and the farmer's perception of the agro ecological conditions of the farm.

- Method of measuring the risk attitude with three components of Bard [16]. This scale was implemented on grain producers in the United States. The method consists of three components: The risk attitude scale, a self-assessment question and a model based on the expected utility.

- The Multiple Price List "Lotteries" (MPL), of Olbrich, Quaas, and Baumgärtner, based on the Theory of Expected Utility (EUT), was implemented to analyze the risk attitude of livestock producers in Namibia's pastures using the MPL format [42], proposed by Binswanger [43] and studied by Holt and Laury [28].

In this case study, the method selected to measure the farmers' risk attitudes was the MLP proposed by Holt and Laury [28], specifically the variant developed by Brick, Visser and Burns [44]. This decision was taken because of the characteristics of the study target population, which does not have a high level of education, but is familiar with the concept of lotteries. The selected method is also characterized by simplicity and a relatively short time for data collection. In addition, its application does not require prior knowledge of the concepts of uncertainty and risk, nor extensive analysis of multiple statements. The MPL method has been used in many studies to measure the risk attitudes of farmers, among which are those made by Olbrich et al. [42] and Brick et al. [44].

\section{Materials and Methods}

The data collected correspond to a representative sample of a total of 370 farmers from irrigation district DR076, and the sample size was determined based on the formula of finite populations, with a confidence level of $95 \%$ and an error level of $4.99 \%$ [45]. The data collection was carried out in a stratified way through a semi-structured face-to-face questionnaire, carried out during the 
period from October to December 2017, with the purpose of identifying factors affecting farmers' risk attitudes. These factors were classified into socio-economic variables that include the particular farmer characteristics, the farm descriptors and main crops, as well as the environmental opinions and attitudes of farmers and their perceptions of weather patterns changes (the translated questionnaire is available in supplementary file Q_1). On average, the application of the interview lasted $40 \mathrm{~min}$ with each farmer and was carried out with the support of a group of students from the Intercultural Autonomous University of Sinaloa, who were instructed prior to the application of the survey. The following methodological approach is summarized in Figure 2.

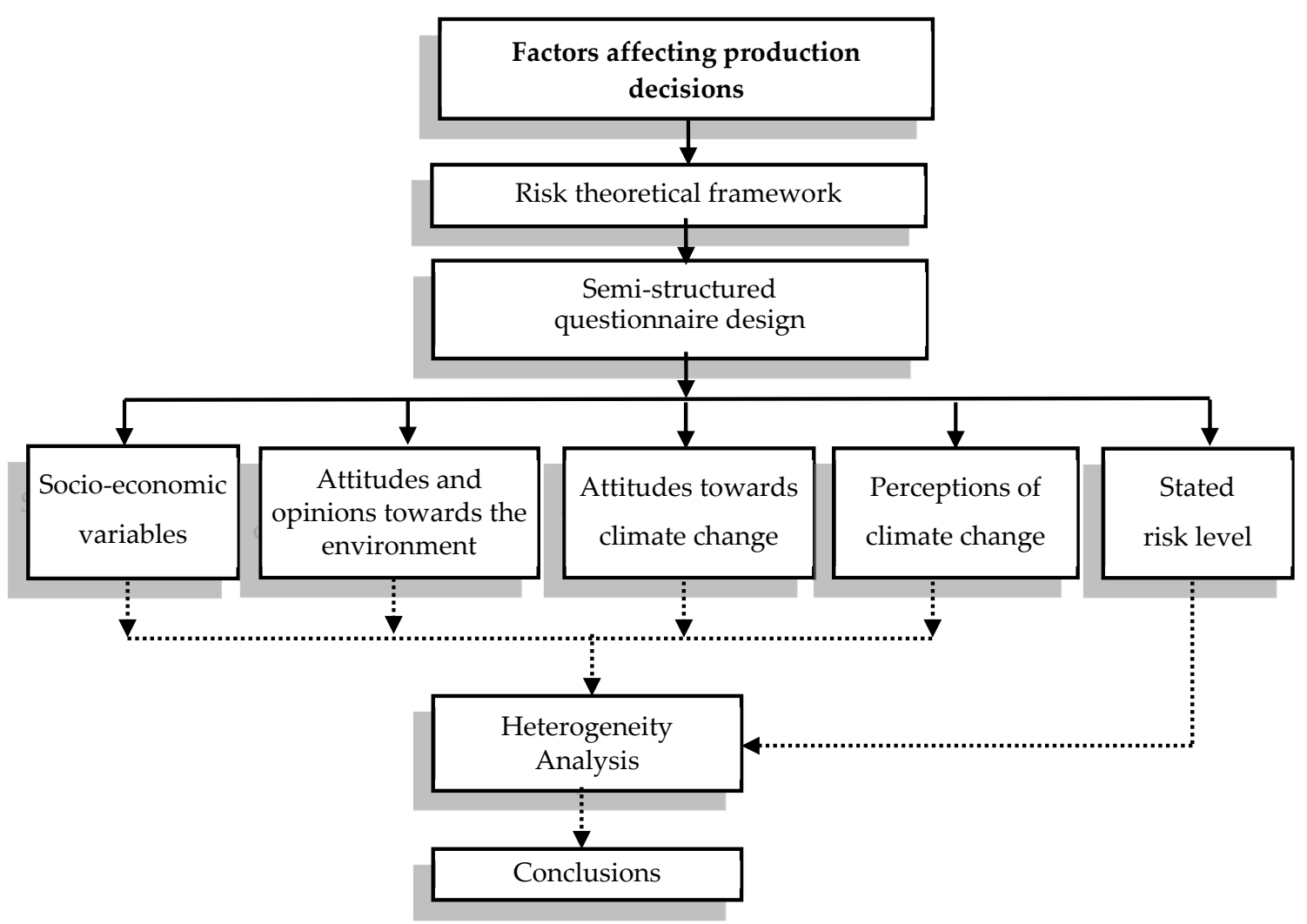

Figure 2. Methodological research approach.

The main variables, describing the 370 farmers, their perceptions, opinions and farm characteristics, are described in Tables 1 and 2.

Each farmer was presented with a questionnaire, with open-ended questions divided into several blocks according to the type of information, collected and presented in Tables 1 and 2 . This questionnaire was tested before its final application on a sample of about 25 farmers. The blocks of variables were: (i) Farmers' socio-economic variables, farm characteristics (economic and management), investment and land use, following the classification presented by Kallas et al. [13], (ii) environmental attitudes and opinions, using the New Ecological Paradigm Scale NEP [46], (iii) attitudes or willingness to carry out actions to reduce climate change using an array of statements evaluated by farmers, (iv) perception of climate change constructed from literature, and (v) attitudes toward risk using the MPL method. The methods used are described below: 
Table 1. The description of farmers, their perceptions and opinions. SD: Standard Deviation.

\begin{tabular}{|c|c|c|c|}
\hline Variables & Percentage (\%) & & \\
\hline \multicolumn{4}{|l|}{ Gender } \\
\hline Male & $88.92 \%$ & & \\
\hline Female & $11.08 \%$ & & \\
\hline \multicolumn{4}{|l|}{ Age } \\
\hline Under 40 years & $19.46 \%$ & & \\
\hline From 41 to 60 years old & $52.16 \%$ & & \\
\hline Above 60 years & $28.38 \%$ & & \\
\hline \multirow[t]{2}{*}{ Percentage of income from agriculture (\%) } & $76.00 \%$ & & \\
\hline & Mean & SD & Units \\
\hline Number of members of the family & 3.79 & 1.74 & members \\
\hline Generations of the family dedicated to agriculture & 2.28 & 0.83 & members \\
\hline \multicolumn{4}{|c|}{ Farmers' understanding about aspects related to global warming (\%) } \\
\hline Melting of the poles & $18.38 \%$ & & \\
\hline Rising temperature and warming of the earth & $52.97 \%$ & & \\
\hline Pollution & $13.92 \%$ & & \\
\hline Emission of gases into the atmosphere & $14.73 \%$ & & \\
\hline
\end{tabular}

Farmers' opinions on the level of improvement required in his activity on a scale from 0 (not required at all) to 10 (absolutely required):

$\begin{array}{ccc}\text { Commercialization of crops } & 8.28 & 2.69 \\ \text { Fight against diseases or pests } & 7.25 & 3.14 \\ \text { Choice of crops } & 6.24 & 3.45 \\ \text { Quality of the soil } & 6.84 & 3.39 \\ \text { Type of tillage } & 7.32 & 3.07 \\ \text { Use of efficient irrigation techniques } & 7.06 & 3.48\end{array}$

\begin{tabular}{ccc}
\hline Farmers' perceptions on climate change on a scale from $\mathbf{0}$ (not observed at all) to $\mathbf{1 0}$ (highly observed): \\
The temperature has increased & 7.46 & 2.32 \\
The level of precipitation has changed & 6.72 & 2.87 \\
The rain periods have changed their temporality & 6.86 & 2.79 \\
The soil has less fertility & 6.24 & 2.96 \\
The periods of drought have increased & 6.56 & 2.79 \\
The harvest has decreased & 6.72 & 2.82 \\
There have been more episodes of droughts & 6.61 & 2.92 \\
There have been more episodes of frost & 5.98 & 3.20 \\
There have been more episodes of floods & 6.85 & 2.68 \\
There have been more episodes of hail & 6.08 & 3.12 \\
There have been more diseases and pests & 8.23 & 1.31 \\
Weeds have increased & 7.92 & 1.88 \\
\hline
\end{tabular}

Farmers' level of willingness to perform the following actions on a scale from 0 (not willing) to 10

Perform only nightly irrigation

Use low-polluting machinery

Carry out agro ecological production

Use renewable energy sources

Do not burn biomass (stubble)

Use non-nitrogenous fertilizers

Use the zero tillage method (completely willing):

$\begin{array}{ll}5.53 & 3.80 \\ 8.02 & 2.62 \\ 7.89 & 2.50 \\ 7.91 & 2.52 \\ 8.01 & 3.26 \\ 7.99 & 2.53 \\ 6.60 & 3.58\end{array}$


Table 2. The description of the farms and main crop activities.

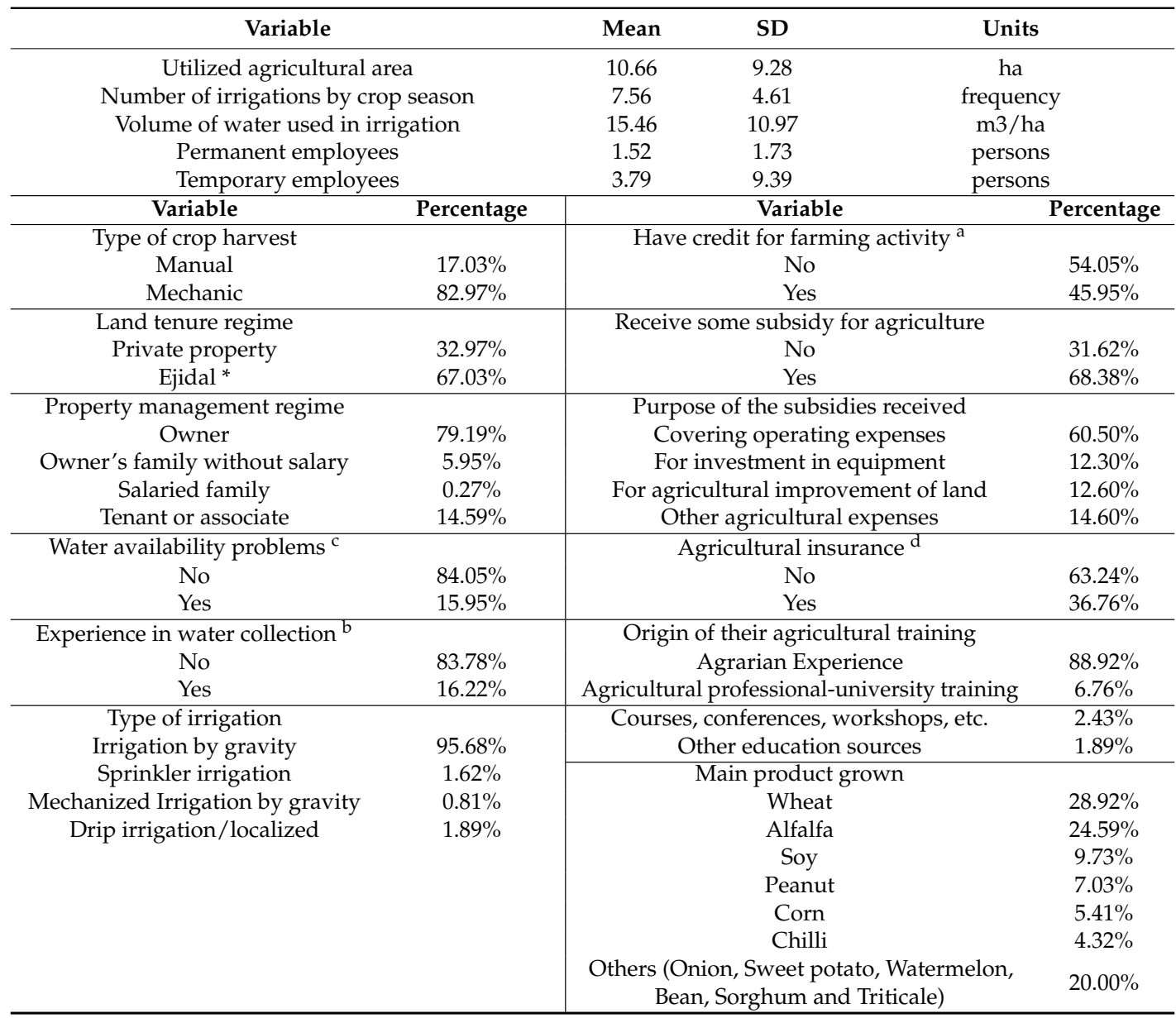

\footnotetext{
${ }^{*}$ Form of farmers' organizations in Mexico. ${ }^{\text {a }}$ Refers to whether the farmer received a credit loan for his agricultural activity. ${ }^{b}$ Indicates if the farmer has used some method to recollect water for crops, such as ponds or dams. ${ }^{\mathrm{c}}$ Refers to the problems related to the water availability in their agricultural land, such as a time-restricted access to water resources and the payment of the water quota. ${ }^{\mathrm{d}}$ Refers to whether farmers hired an insurance contract for their crops.
}

\subsection{Measuring Farmers' Environmental Attitudes and Opinions}

The NEP scale was used to analyze farmers' environmental opinions. This scale has sixteen statements (Table 3) that express a positive or negative evaluation of the environment and relies on individual's beliefs about themselves and nature, according to a nine-point Likert type scale, where 1 means absolutely disagree, and 9 means absolutely agree $[47,48]$. To understand the behavior that humans have toward the environment, it is necessary to understand how they perceive it, that is, what their pro-environmental attitudes are. By performing a factorial analysis using the NEP scale, the dimensionality that characterizes farmers can be identified to determine if the items are clearly associated with an array of dimensions. The NEP scale has been used to analyze farmers' beliefs concerning environmental issues [49]. This scale reflects the way in which the human being conceptualizes nature and the way he/she behaves in relation to it [48]. 
Table 3. Statements of the New Ecological Paradigm Scale.

\begin{tabular}{|c|c|c|c|c|c|c|c|c|}
\hline $\begin{array}{c}\text { Absolutely } \\
\text { Disagree }\end{array}$ & $\begin{array}{l}\text { Strongly } \\
\text { Disagree }\end{array}$ & $\begin{array}{c}\text { Moderately } \\
\text { Disagree }\end{array}$ & $\begin{array}{l}\text { Slightly } \\
\text { Disagree }\end{array}$ & Neutral & $\begin{array}{l}\text { Slightly } \\
\text { Agree }\end{array}$ & $\begin{array}{c}\text { Moderately } \\
\text { Agree }\end{array}$ & $\begin{array}{c}\text { Strongly } \\
\text { Agree }\end{array}$ & $\begin{array}{c}\text { Absolutely } \\
\text { Agree }\end{array}$ \\
\hline 1 & 2 & 3 & 4 & 5 & 6 & 7 & 8 & 9 \\
\hline $\begin{array}{l}\text { 1. A glol } \\
\text { 2. The b } \\
\text { 3. Hum } \\
\text { 4. Hum } \\
\text { 5. Hume } \\
\text { 6. Hum } \\
\text { 7. The ir } \\
\text { 8. Plants } \\
\text { 9. The h } \\
\text { 10. The b } \\
\text { 11. If thir } \\
\text { 12. We ar } \\
\text { 13. The e } \\
\text { 14. Desp } \\
\text { 15. The la } \\
\text { 16. Susta }\end{array}$ & $\begin{array}{l}\text { l ecological } \\
\text { ance of nat } \\
\text { s may be ab } \\
\text { ingenuity } \\
\text { s were crea } \\
\text { s have the r } \\
\text { erference of } \\
\text { and animals } \\
\text { man being s } \\
\text { lance of nat } \\
\text { s continue } \\
\text { approachin } \\
\text { th has limit } \\
\text { our specia } \\
\text { d has abun } \\
\text { able develo }\end{array}$ & $\begin{array}{l}\text { risis is exagge } \\
\text { e supports th } \\
\text { e to control na } \\
\text { sures that the } \\
\text { d to dominate } \\
\text { ht to modify } \\
\text { he human bei } \\
\text { lave the same } \\
\text { riously abuse } \\
\text { e is delicate a } \\
\text { they have be } \\
\text { the limit num } \\
\text { d resources. } \\
\text { abilities, hum } \\
\text { ant resources, } \\
\text { ment needs a }\end{array}$ & $\begin{array}{l}\text { med. } \\
\text { mpact of in } \\
\text { are. } \\
\text { arth is not } \\
\text { he rest of } n \\
\text { e environm } \\
\text { in nature } 1 \\
\text { ght to exist } \\
\text { he environ } \\
\text { d easily alte } \\
\text {, we will so } \\
\text { er of people } \\
\text { beings are } \\
\text { re just have } \\
\text { alanced situ }\end{array}$ & $\begin{array}{l}\text { ustrialized } \\
\text { inhabitab } \\
\text { ure. } \\
\text { nt to adap } \\
\text { s disastro } \\
\text { human b } \\
\text { ent. } \\
\text { ble. } \\
\text { n experier } \\
\text { hat the ea } \\
\text { ill subject } \\
\text { learn hor } \\
\text { tion that c }\end{array}$ & $\begin{array}{l}\text { ountries. } \\
\text { to their n } \\
\text { consequer } \\
\text { ngs. } \\
\text { a great ec } \\
\text { can hold. } \\
\text { the laws c } \\
\text { to exploit t } \\
\text { trols indus }\end{array}$ & $\begin{array}{l}\text { la } \\
\text { ds. } \\
\text { ogical catastro } \\
\text { nature. } \\
\text { ial growth. }\end{array}$ & & \\
\hline
\end{tabular}

\subsection{Measuring Farmers' Perceptions of Climate Change}

The perception of climate change involves the analysis, according to each farmer, of whether he/she has observed variability in certain meteorological factors or events related to the climate. To address this issue, an array of statements, collected from a literature review (Table 4) and related to climate change was evaluated, according to the farmer's own perception, on a 9-point Likert type scale (from 1 to 9), where 1 means absolutely disagree, and 9 means absolutely agree.

Table 4. Items included analyzing the farmers' perceptions of climate change.

\begin{tabular}{|c|c|c|c|c|c|c|c|c|}
\hline $\begin{array}{c}\text { Absolutely } \\
\text { Disagree }\end{array}$ & $\begin{array}{l}\text { Strongly } \\
\text { Disagree }\end{array}$ & $\begin{array}{l}\text { Moderately } \\
\text { Disagree }\end{array}$ & $\begin{array}{c}\text { Slightly } \\
\text { Disagree }\end{array}$ & Neutral & $\begin{array}{l}\text { Slightly } \\
\text { Agree }\end{array}$ & $\begin{array}{c}\text { Moderately } \\
\text { Agree }\end{array}$ & $\begin{array}{l}\text { Strongly } \\
\text { Agree }\end{array}$ & $\begin{array}{c}\text { Absolutely } \\
\text { Agree }\end{array}$ \\
\hline 1 & 2 & 3 & 4 & 5 & 6 & 7 & 8 & 9 \\
\hline $\begin{array}{l}\text { In the last } 10 \\
\text { In the last } 10 \\
\text { In the last } 10 \\
\text { In the last } 10 \\
\text { In the last } 10 \\
\text { In the last } 10 \\
\text { In the last } 10 \\
\text { In the last } 10 \\
\text { In the last } 10 \\
\text { In the last } 10 \\
\text { In the last } 10 \\
\text { In the last } 10\end{array}$ & $\begin{array}{l}\text { ears you has } \\
\text { ears you has } \\
\text { ears you hav } \\
\text { ears you hav } \\
\text { ears you hav } \\
\text { ears you hav } \\
\text { ears you hav } \\
\text { ears you hav } \\
\text { ears you hav } \\
\text { ears you hav } \\
\text { ears you hav } \\
\text { ears you hav }\end{array}$ & $\begin{array}{l}\text { noticed that } t \\
\text { noticed that } t \\
\text { noticed that } r \\
\text { noticed that } t \\
\text { noticed that } t \\
\text { noticed that } t \\
\text { noticed that } t \\
\text { noticed that } t \\
\text { noticed that } t \\
\text { noticed veget }\end{array}$ & $\begin{array}{l}\text { e temperatu } \\
\text { e level of pr } \\
\text { in periods } \mathrm{l} \\
\text { e soil has lo } \\
\text { e periods of } \\
\text { e harvest ha } \\
\text { ere have be } \\
\text { ere have be } \\
\text { ere have be } \\
\text { ere have be } \\
\text { ere have be } \\
\text { tion change }\end{array}$ & $\begin{array}{l}\text { e has incre } \\
\text { cipitation } \\
\text { ve change } \\
\text { fertility: } \\
\text { lrought h } \\
\text { decreasec } \\
\text { more ep } \\
\text { more ep } \\
\text { more ep } \\
\text { more epi } \\
\text { more dis } \\
\text { [60] }\end{array}$ & $\begin{array}{l}\text { ed: [50,51] } \\
\text { s changed: } \\
\text { their temp } \\
54] \\
\text { increased } \\
56] \\
\text { des of drot } \\
\text { des of fros } \\
\text { des of floo } \\
\text { des of Hail } \\
\text { ses and pes }\end{array}$ & $\begin{array}{l}0,52] \\
\text { lity: [53-55] } \\
50,52] \\
\text { tts: [3,50] } \\
\text { 50,53] } \\
{[52]} \\
57] \\
{[58,59]}\end{array}$ & & $\begin{array}{c} \\
\\
\end{array}$ \\
\hline
\end{tabular}

\subsection{Measuring Farmers' Risk Attitudes}

\subsubsection{Model Definition}

Each respondent was presented with a set of different lottery pairs, and one of the lottery options must be chosen from each pair [61]. (This relates the levels of risk aversion with a prize or profit). In the definition of the model, a list of eight scenarios was generated, with a pair of hypothetical lotteries, called option A and option B, which is similar to the theoretical model used by Brick et al. [44]. In this model, as in Brick's, the probabilities that each one of the options will keep the experiment as simple as possible remain constant. In option $\mathrm{A}$, the probability of obtaining the amount presented was set at $100 \%$ (safe option), and in option B (risky option), the probability was set at $50 \%$ for obtaining the amount of (\$100) and 50\% for not getting anything (\$0) (tossing a coin for heads or tails) in all scenarios, while the safe amount presented in option A in each of the eight scenarios is modified in a decreasing manner, according to the following amounts $(\$ 100, \$ 75, \$ 60, \$ 50, \$ 40, \$ 30, \$ 20$ and $\$ 10)$. 
The level of risk aversion is based on the number of safe answers (option A) that the interviewee selects. According to the experimental design structure (see question 35 in the questionnaire, available in the supplementary file Q_1), only a risk-tolerant participant would select option B in the first scenario, while an extremely risk-averse participant would be the one who, in the eight scenarios, would select option $B$, and a risk-neutral participant would be the one who selects option A in the first three scenarios, and in the fourth scenario, changes to option B [62].

\subsubsection{Estimation of the Relative Risk Aversion Coefficient " $r$ "}

We defined the values of the Constant Relative Risk Aversion (CRRA), based on the function, $U(y)=y^{(1-r)} /(1-r)$, where $\mathrm{y}$ is the income and $\mathrm{r}$ the relative risk aversion coefficient for each of the six stages (Table 5). Then, the coefficient $r$ is estimated by means of the logarithmic maximum likelihood function, conditioned to the expected utility model and the CRRA specification, defined as the difference of the expected utility $\left(\nabla \mathrm{EU}=\mathrm{EU}_{\mathrm{A}}-\mathrm{EU}_{\mathrm{B}}\right)$. In this case, the maximum likelihood equation used is:

$$
\ln \mathrm{L}^{\mathrm{EU}}(r, z, X)=\sum_{i}((\ln (\nabla \mathrm{EU}) / z=1)+(\ln (1-\nabla \mathrm{EU}) / z=0))
$$

where $z_{i}=(0,1), 1$ indicates that the respondent chose the auction in scenario $i, 0$ indicates that he/she chose the safe amount, and $X$ corresponds to a vector of variables of personal, agricultural and environmental characteristics and environmental risk. Once the structure of the experiment is established, according to the specification of the choice of theory of expected utility (EUT) under uncertainty, the parameters of the function of CRRA are estimated, which allow the behavior or risk preferences of participants to be modelled [44,63]. According to the theory of the expected utility (EUT, Expected Utility Theory), proposed by von Neumann-Morgenstern, different utility functions have been generated that shape the behavior of people according to their risk preferences. Among the most common is the CRRA, which allows the implicit risk in decision making to be estimated [37].

The expected utility of each lottery is calculated by means of the function:

$$
\mathrm{EU}=\sum_{i}\left(p_{i} \times U\left(X_{i}\right)\right)
$$

where $p_{i}$ is the probability of occurrence of the utility of the prize $X i$, and $\mathrm{U}\left(X_{i}\right)$ is the utility of the prize $X_{i}$. The CRRA function is defined as a non-negative lottery prize, according to the following equation:

$$
U(X)=\frac{X^{1-r}}{1-r}
$$

where $X$ corresponds to the lottery prize, $r$ is the latent risk aversion coefficient, where $r=0$ indicates

\begin{tabular}{|c|c|c|c|c|}
\hline \multirow{2}{*}{$\frac{\text { Number of Safe Choices "A" }}{0-1}$} & \multicolumn{3}{|c|}{ Range of CRRA for $\mathrm{U}(X)=X^{(1-r)} /(1-r)$} & \multirow{2}{*}{$\begin{array}{c}\text { Classification of Risk Preference } \\
\text { highly risk-tolerant }\end{array}$} \\
\hline & -1.71 & $\mathrm{r}<$ & -0.95 & \\
\hline 2 & -0.95 & $>\mathrm{r}<$ & -0.49 & very risk-tolerant \\
\hline 3 & -0.49 & $>\mathrm{r}<$ & -0.15 & risk-tolerant \\
\hline 4 & -0.15 & $>\mathrm{r}<$ & 0.14 & risk-neutral \\
\hline 5 & 0.14 & $>\mathrm{r}<$ & 0.41 & slightly risk-averse \\
\hline 6 & 0.41 & $>r<$ & 0.68 & risk-averse \\
\hline 7 & 0.68 & $>\mathrm{r}<$ & 0.97 & very risk-averse \\
\hline 8 & 0.97 & $>r<$ & 1.37 & highly risk-averse \\
\hline
\end{tabular}
risk neutrality, $r>0$ indicates risk aversion, and $r<0$ indicates taste or tolerance for risk [63].

Table 5. Level of risk coefficients [28].

To determine CRRA values, a scenario and its immediate continuum are related, given that each scenario is independent of the rest, and the model is defined with a decreasing level of risk aversion, so it is not necessary to relate it to the subsequent scenarios, meaning that the level of risk aversion is 
determined by the first change of option A by option B. (Because of this, any inconsistency subsequent to $\mathrm{B}^{\prime} \mathrm{s}$ decision can be eliminated).

For instance, the choices of an individual, who chooses option $\mathrm{A}$ in the first three scenarios and then changes to option $B$, correspond to a risk aversion coefficient in the range of -0.15 and 0.14 , which would define the individual as risk-neutral, while a person who always chooses Option A (the secure lotteries), the CRRA rank that corresponds to it is $0.97-1.37$, which defines the person as extremely risk-averse.

The expected values of options A and B in each of the scenarios of the experimental design can be seen in Table 6 . This also includes the ranges of relative risk aversion coefficients, implicit in each possible choice, under the assumption of the constant relative risk aversion (CRRA).

Table 6. Matrix of payments in the risk aversion experiment.

\begin{tabular}{|c|c|c|c|c|c|c|c|c|c|c|}
\hline \multirow{2}{*}{$\begin{array}{c}\text { Lottery } \\
\text { Question (Scenario) }\end{array}$} & \multicolumn{2}{|c|}{ Option A } & \multicolumn{4}{|c|}{ Option B } & \multicolumn{3}{|c|}{ Expected Value } & \multirow{2}{*}{ CRRA* Interval } \\
\hline & A & PA * & B1 & PB1 * & B2 & PB2 * & $\mathrm{E}(\mathrm{A})$ & $E(B)$ & Difference & \\
\hline 1 & 100 & 1 & 100 & 0.5 & 0 & 0.5 & 100 & 50 & 50 & $-1.71,-0.95$ \\
\hline 2 & 75 & 1 & 100 & 0.5 & 0 & 0.5 & 75 & 50 & 25 & $-0.95,-0.49$ \\
\hline 3 & 60 & 1 & 100 & 0.5 & 0 & 0.5 & 60 & 50 & 10 & $-0.49,-0.15$ \\
\hline 4 & 50 & 1 & 100 & 0.5 & 0 & 0.5 & 50 & 50 & 0 & $-0.15,0.14$ \\
\hline 5 & 40 & 1 & 100 & 0.5 & 0 & 0.5 & 40 & 50 & -10 & $0.14,0.41$ \\
\hline 6 & 30 & 1 & 100 & 0.5 & 0 & 0.5 & 30 & 50 & -20 & $0.41,0.68$ \\
\hline 7 & 20 & 1 & 100 & 0.5 & 0 & 0.5 & 20 & 50 & -30 & $0.68,0.97$ \\
\hline 8 & 10 & 1 & 100 & 0.5 & 0 & 0.5 & 10 & 50 & -40 & $0.97,1.37$ \\
\hline
\end{tabular}

$\mathrm{PA}^{*}$, Probability option A; PB1*, probability of winning the amount B1 of option B; PB2*, probability of winning the amount B2 of option B; CRRA*, Constant relative risk aversion.

Once the CRRA values are estimated, the choices made by each individual on each pair of options presented in the eight scenarios are taken, and their level of aversion to individual risk is estimated. The instructions and differences regarding the lotteries presented in each scenario were explained in detail to farmers. Then, they were given the sheet to make their choices. The level of individual risk was determined and the group results were subsequently aggregated.

By means of contingency tables and the analysis of variance by means of the ANOVA method, the relationship of the data with the variable response level of aversion to risk, presented by the farmers, is explored. Subsequently, the statistical technique of Principal Component Analysis (PCA) was used to reduce the dimensionality based on the estimation of correlations. The obtained results are interpreted, characterizing the farmers of the studied regions.

\section{Results and Discussion}

\subsection{Results on the Level of Farmers' Risk Attitudes}

The results of the estimated risk level using the MPL showed a score of about 0.32 , which globally defines the studied population as slightly risk-averse, according to the aforementioned scale of Holt and Laury. The results presented in Figure 3 showed the distribution of the sample of farmers, according to the different estimated scores of the attitudes towards risk levels. According to the scale of Holt and Laury [28], the results showed that almost 34\% of farmers are highly risk-averse, $7.57 \%$ are risk-neutral, and $22 \%$ of farmers are highly risk-tolerant. These results are similar to those of Trujillo et al. (2009) [64], Galarza (2009) [65], Pennings and Garcia (2001) [17] and Brick et al. (2011) [44], who found that farmers exhibited, in general, a risk-averse attitude. 

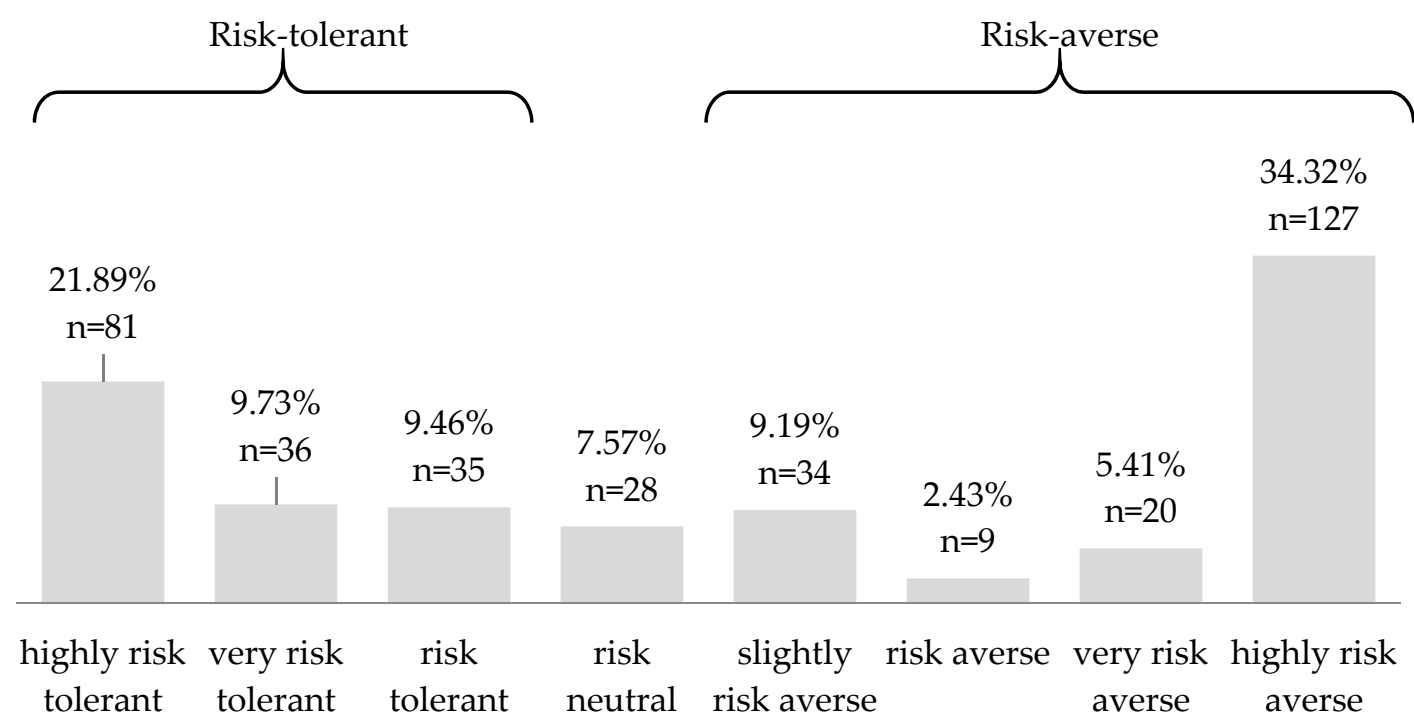

Figure 3. Distribution of the farmers according to their risk level. $n$ : numbers.

\subsection{Risk Heterogeneity Analysis}

The risk response (risk-CRRA) is a categorical variable and represents the risk level of the farmers according to the scale used by Holt and Laury. The results of the heterogeneity analysis indicate that the variables related to the level of risk aversion are: The purpose of the subsidies received ( $p$-value $=$ $0.002)$, the gender of the agricultural producer $(p$-value $=0.046)$ and the age $(p$-value $=0.000)$. Results showed that women consider themselves a bit more risk-tolerant than their counterparts (percentage of men who tolerate risk $=39 \%$, while the percentage of women who tolerate risk $=61 \%$ ). The average level of estimated risk for women was -0.035 , and the estimated risk level of men was 0.361 . This result should be taken into account, particularly because women are responsible for $60 \%$ to $80 \%$ of the world's food, and they are better stewards of the environment [66]. Furthermore, women are more prone to participating in extensive activities related to agriculture and are more committed to farming activities. However, decisions that are related to farm development and improvement adoption are taken by men, excluding women in the decision-making process of a new agricultural system [67].

The variable collecting the main use of the subsidies was highly related to farmers' risk level. Farmers who receive economic support and use it in structural investment at the farm level are more risk-tolerant, while those who do not have an adverse profile to risk [68]. Age was also associated with the risk level, which is similar to the findings of Brick et al., in their experiment on African fishing communities [44]. In our case, we found that farmers "above 60 years of age" show that the experience acquired over time allows them to have a lower risk aversion on average, compared to farmers in the range of 41 to 60 years' old, who are more conservative, with a higher level of risk aversion.

Several pieces of agricultural economic research, which measured risk attitudes according to the expected utility theory, found that they are related to a set of farm and farmers' variables. Fahad et al. (2018) mentioned that factors, such as age, farming experience, and land size, may influence the farmers' decisions to contract crop insurance as a risk management strategy [14]. De Pinto et al. (2013) found that the implications for climate change mitigation projects are related to farmers' risk level [69]. Dörschner and Musshoff (2013) mentioned that the income variation and the farmers' risk attitudes can constitute an explanatory approach for the low acceptance of the actions that face the impact of climate change, showing that a better understanding of farmers' risk attitudes is necessary to make more effective agricultural policies [70].

The variables shown in Table 7, correspond to the attitudinal variables included in the heterogeneity analysis relating the risk level and attitudes associated with, and perception of, the environment and climate change. 
Table 7. Variables related to the level of risk based on the ANOVA, classified by the type of information.

Type of Information
$\begin{gathered}\text { Vuriables } \\ \text { Utilized agricultural area } \\ \text { Volume of water used in irrigation } \\ \text { Income } \\ \text { Percentage of income from agriculture }\end{gathered}$
Attitudes and Opinions towards the Environment (NEP Statements)
A global ecological crisis is exaggerated
The balance of nature supports the impact of industrialized countries
Humans may be able to control nature
Human ingenuity ensures that the earth is not uninhabitable
The interference of the human being in nature has disastrous consequences
The human being seriously abuses the environment
The balance of nature is delicate and easily alterable
We are approaching the limit number of people that the earth can hold
The earth has limited resources
The land has abundant resources, we just have to learn how to exploit them
Sustainable development needs a balanced situation that controls industrial growth
Attitudes towards Climate Change
Level of disposition to perform only nightly irrigation
Level of willingness to use low-polluting machinery
Level of disposition to carry out agro ecological production
Level of disposition to use of renewable energy sources
Level of disposition not to burn biomass (stubble)
Level of willingness to use non-nitrogenous fertilizers
Level of willingness to use zero tillage
Perception of Climate Change
Level of impact of global warming on their crops
Percentage of climate change influence on production costs
Temperature increase
More episodes of floods
More episodes of hail
More diseases and pests
Weed increase

Source: Own elaboration, based on the data provided by the interviewees.

Given that farmers perceive that they have a significant interest with respect to climate change, we reduced the dimensionality of this group of variables, seeking a minimum loss of information through a Principal Components Analysis (PCA). The objective is to determine a smaller set of unrelated variables that explain the existing relationships between the observed variables, identify the number of underlying variables, evaluate the individuals in relation to these new variables, and interpret the extracted component. Before starting the analysis, the Kaiser Meyer Olkin test (KMO) was applied to verify the applicability of the set of available variables. The results obtained, of 0.697 and 0.74 , indicating that the relation of these is between medium and low.

The results of the PCA allowed two components to be identified, which explain $51 \%$ of the total variability. The first factor identified is defined by the climatic variables, such as floods, hail, diseases and pests. The second factor is defined by variables related to the impact of climate change on the farming activity, with variables related to weed increase, the impact of the global warming on crops and the influence of climate change on production. These results indicated that the first component characterizes the perception of farmers towards the negative weather patterns, and the second is related to the impact on their agricultural productivity.

The distribution of the point's cloud, which represents the farmers in relation to the two main components and the variables previously described, is shown in Figure 4. Most of the risk-tolerant farmers (red points) are located to the right of the first dimension, exhibiting a higher perception of the weather patterns related to climate change, compared to the risk-averse farmers. This result is similar to the finding of Pomareda (2008) [71] and Brown et al. (2017), who found that effect of natural shocks affects risk attitudes and perceptions [72]. Furthermore, risk-tolerant farmers (red points) are more 
concentrated in the upper part of the second dimension, showing that they perceive to a greater extent that climate change has a high impact on their production. In this context, our results showed that the highly risk-tolerant farmers are those that are prone to using subsides in structural investment at the farm level. The results also showed that risk-neutral farmers do not have well-defined perceptions regarding climate change, nor the effects that climate change could have on their productivity.

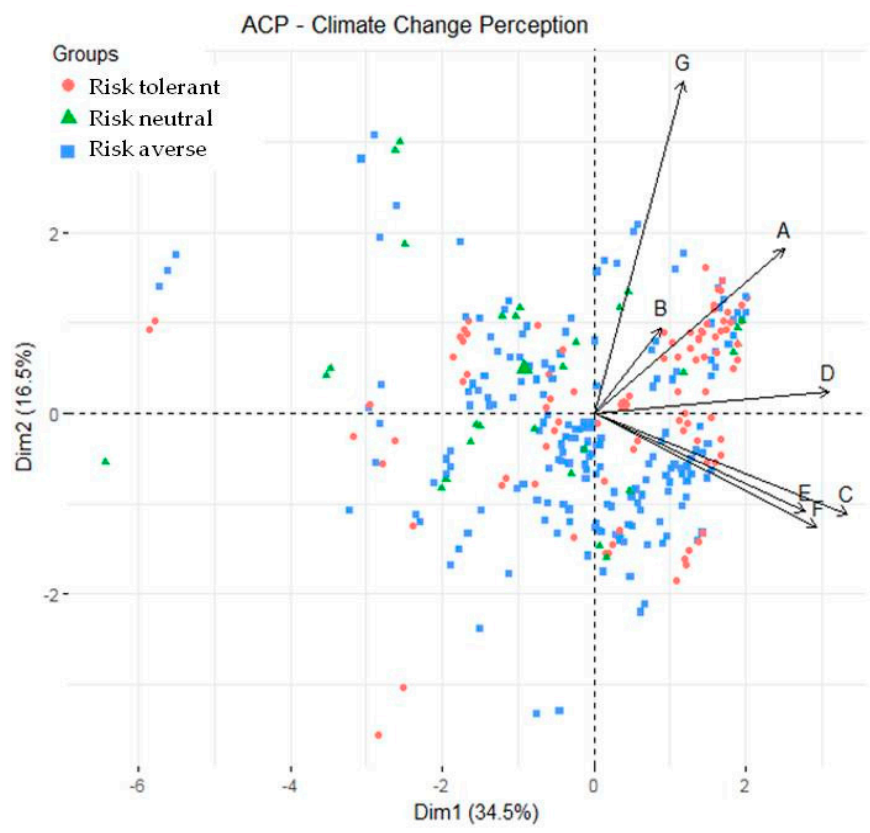

Figure 4. Distribution of farmers according to their perceptions of climate change. (A) Impact of global warming on their crops; (B) Percentage of climate change influence on production costs; (C) Temperature increase; (D) More episodes of floods; (E) More episodes of hail; (F) More diseases and pests; (G) Changes in weed development.

The result of PCA, carried out on farmers' opinions and attitudes towards the environment, using the NEP scale and their relation to risk level, is presented in Figure 5. As can be seen, the first two components explain an accumulated variance of $47.4 \%$. The first factor was principally defined by the variables, "The earth has limited resources" and "Sustainable development needs a balanced situation". This factor can be characterized as an ecocentric attitude. The second factor was mainly defined by the variables, "Humans may be able to control nature", "The balance of nature supports the impact of industrialized countries", and "Human ingenuity ensures that the earth is not uninhabitable," which are related to an anthropocentric attitude towards the environment [73].

Based on the points dispersion, the results showed that farmers with a risk-tolerant attitude (red points) have a positive perception regarding the aspects related to ecocentric attitudes. The risk-tolerant farmers are those that allow for better differentiation of the aspects related to their positive environmental opinions. They have a clearer vision of the aspects related to their positive environmental opinions. Furthermore, in this context, risk-tolerant farmers are willing to perform positive actions relating to the environment, such as using low-polluting machinery, not burning biomass (stubble) or using non-nitrogenous fertilizers (identified in Table 7), while there is no clear trend in the environment opinions of risk-averse farmers. However, their risk-averse attitude does not preclude their potential adoption of positive actions towards the environment, as stated in Dörshner and Musshoff (2013) [70]. 


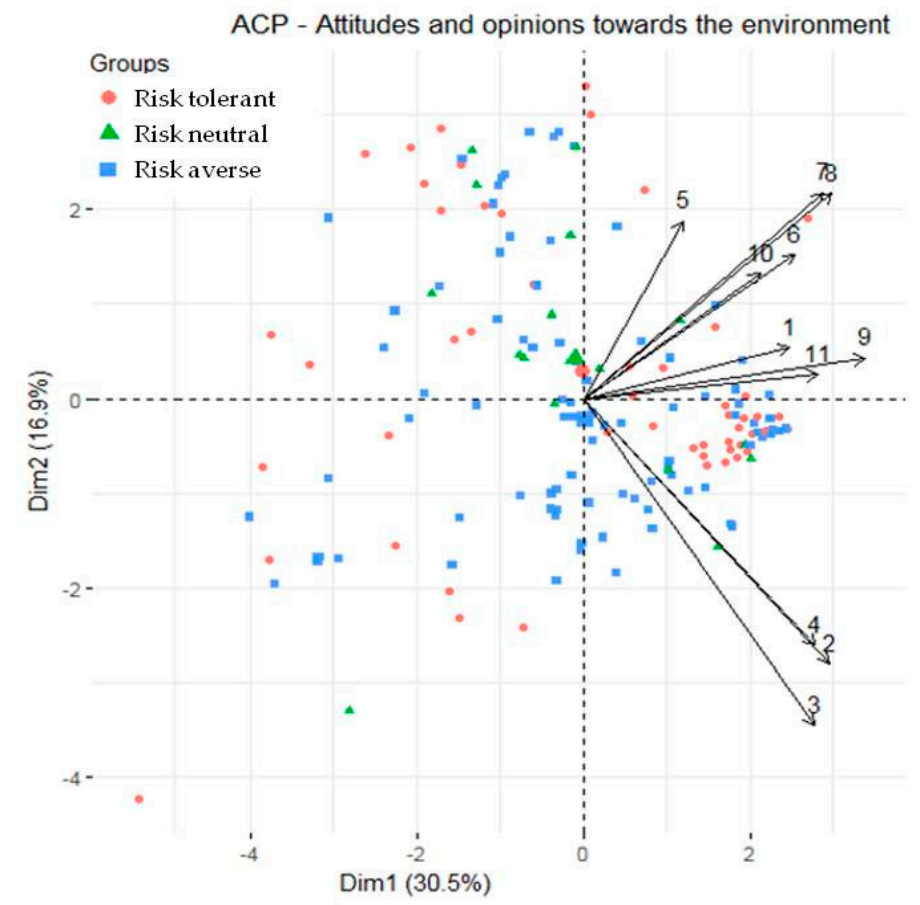

Figure 5. Distribution of farmers, interviewed according to their environmental opinions. (1) A global ecological crisis is exaggerated; (2) The balance of nature supports the impact of industrialized countries; (3) Humans may be able to control nature; (4) Human ingenuity ensures that the earth is not uninhabitable; (5) The interference of the human being in nature has disastrous consequences; (6) The human being seriously abuses the environment; (7) The balance of nature is delicate and easily alterable; (8) We are approaching the limit number of people that the earth can hold; (9) The earth has limited resources; (10) The land has abundant resources; we just have to learn how to exploit them; (11) Sustainable development needs a balanced situation.

\section{Conclusions}

There is a wide variety of stated methods for measuring the risk level in the agricultural sector, although the MPL method (lotteries) is shown to be a valid approach in the agricultural sector. It is characterized by its simplicity and is easily understood. Furthermore, its application does not require prior knowledge of the concepts of uncertainty and risk, nor extensive analysis of multiple statements. In general, in the studied area, farmers do not have high academic preparation, which makes the MPL a suitable method in this case. The MPL is a useful tool for comparing the stated risk attitudes of individuals who face the same lottery game.

The farmers in the studied region exhibited, in general terms, a risk-averse attitude, which is consistent with the main finding of other stated approaches to risk studies in the agriculture sector. Farmers recognize the importance of improving the commercialization of their crops and the effectiveness of treatments against diseases and pests. Farmers' perceptions of climate change were highlighted by the adverse effects on their output through higher disease and pest incidences on their crops, weed development increases, temperature increases and variations, and changes in the temporality of the rain periods.

The farmers' characteristics, such as sex and age, were related to their stated risk level. An important finding to highlight is that women in the region were more risk-tolerant than men and were more prone to using public support to invest at the farm level. However, they are marginalized as decision-makers at the policy level and are therefore still less involved in the design and implementation of public policy in the agricultural sector, mainly due to cultural limitations. Our results also showed that farmers above 60 years old are more risk-tolerant than younger farmers. 
As part of the findings of this research, risk-tolerant farmers were shown to be highly aware of the effects of climate change on production and were shown to agree with sustainable development statements concerning the environment, which may generate greater resilience in the region. Better involvement of these farmers in the process of generating agricultural public policies is recommended. Additionally, public policies should effectively target farmers with risk-averse attitudes in order to build confident relationships with them, which may improve their perceptions and adaptive capacities in relation to climate change.

One of the limitations of this paper is that the comparability of the results on the level of risk depends on the use of the MPL method under the same payment scheme, given that the difference in payments can generate heterogeneous results. Thus, for future research, it should be considered that the applicability and validity test using MPL could be verified by its application in other agricultural areas with similar characteristics. This would also corroborate and validate the results, generating a comparative map of attitudes towards risk and climate change perceptions.

Supplementary Materials: The following are available online at http://www.mdpi.com/2073-4395/9/1/4/s1, supplementary file: supplementary file Q_1.

Author Contributions: M.A.O.T. conceived and designed the study, investigates, performed data collection, and wrote manuscript; Z.K. conceived and designed the research, made review and editing, participates in writing the manuscript and was the supervisor of all procedures; S.I.O.H. made the formal analysis of the data and participates in writing the manuscript.

Funding: This research received no external funding.

Acknowledgments: The National Council of Science and Technology (CONACYT) is thanked for the support to carry out this research.

Conflicts of Interest: The authors declare no conflicts of interest.

\section{References}

1. Ministerio de Agricultura, Pesca y Alimentación-Ministerio para la Transición Ecológica. Qué es el Cambio Climático. 2018. Available online: http://www.mapama.gob.es/es/cambio-climatico/temas/cumbrecambio-climaticocop21/el-cambio-climatico/ (accessed on 6 July 2018).

2. Cárdenas, M.J. México Ante El Cambio Clomático: Evidencias, Impactos, Vulnearablidad y Adapatación; Greenpeace: Mexico City, Mexico, 2010; pp. 1-68.

3. Rivera, I.; Di Paola, M. Cambio Climático: Impacto e Incidencias de las Políticas Públicas en el Sector Agropecuario. 2013. Available online: http://www.farn.org.ar/wp-content/uploads/2014/07/ informe2013-1.268-291.pdf (accessed on 6 July 2018).

4. Bonatti, M. Cambios Climáticos, Percepciones Humanas y Desarrollo Rural. Master's Thesis, Universidad de Buenos Aires, Buenos Aires, Argentina, 2011.

5. Makuvaro, V.; Walker, S.; Masere, T.P.; Dimes, J. Smallholder farmer perceived effects of climate change on agricultural productivity and adaptation strategies. J. Arid Environ. 2018, 152, 75-82. [CrossRef]

6. Zhai, S.Y.; Song, G.X.; Qin, Y.C.; Ye, X.Y.; Leipnik, M. Climate change and Chinese farmers: Perceptions and determinants of adaptive strategies. J. Integr. Agric. 2018, 17, 949-963. [CrossRef]

7. Infante, R.K.; Arce, I.A. Percepción local de los servicios ecológicos y de bienestar de la selva de la zona maya en Quintana Roo, México. Investig. Geogr. 2015, 86, 67-81. [CrossRef]

8. Saqib, S.E.; Ahmad, M.M.; Panezai, S.; Rana, I.A. An empirical assessment of farmers' risk attitudes in flood-prone areas of Pakistan. Int. J. Disaster Risk Reduct. 2016, 18, 107-114. [CrossRef]

9. Whitmarsh, L.; Capstick, S. Perceptions of climate change. In Psychology and Climate Change; Clayton, S., Manning, C., Eds.; Academic Press: Cardiff, UK, 2016; pp. 13-33. [CrossRef]

10. Green, S.; O'Donoghue, C. Assessing the Geographic Representativity of Farm Accountancy Data. Int. J. Geo-Inf. 2013, 2, 50-66. [CrossRef]

11. Ayuntamiento de Vitoria Gasteiz. Agenda 21. 2018. Available online: http://app05.ottawa.ca/sirepub/ cache/2/yfoiqw0dd2sygaf2fpln4mim/50206303282018080034948.PDF (accessed on 10 July 2018).

12. Espada, R.L. Percepción de la Ciudadanía Viguesa Sobre el Cambio Climático; Vigo: Galicia, Spain, 2016; 209p. 
13. Kallas, Z.; Serra, T.; Gil, J. Farmers' objectives as determinants of organic farming adoption: The case of Catalonian vineyard production. Agric. Econ. 2010, 41, 409-423. [CrossRef]

14. Fahada, S.; Wanga, J.; Hua, G.; Wanga, H.; Yanga, X.; Ahmad, A.; Lan, N.; Bilald, A. Empirical analysis of factors influencing farmers crop insurance decisions in Pakistan: Evidence from Khyber Pakhtunkhwa province. Land Use Policy 2018, 75, 459-467. [CrossRef]

15. Akhtar, S.; Gu-cheng, L.; Ullah, R.; Nazir, A.; Amjed, M.; Haseeb, M.; Iqbal, N.; Faisal, M. Factors influencing hybrid maize farmers' risk attitudes and their perceptions. Integr. Agric. 2018, 17, 1454-1462. [CrossRef]

16. Bard, S.; Barry, P. Developing a scale for assessing risk attitudes of agricultural decision makers. Int. Food Agribus. Manag. Rev. 2000, 3, 9-25. [CrossRef]

17. Zamasiya, B.; Nyikahadzoi, K.; Billiard, M.B. Factors influencing smallholder farmers' behavioural intention towards adaptation to climate change in transitional climatic zones: A case study of Hwedza District in Zimbabwe. Environ. Manag. 2017, 198, 233-239. [CrossRef]

18. Instituto Municipal de Planeación de Ahome IMPLAN. Available online: http://www.implanahome.gob. $\mathrm{mx} /$ home.html (accessed on 6 July 2018).

19. CONAGUA Comisión Nacional del Agua; Secretaría de Medio Ambiente y Recursos Naturales. Estadísticas Agrícolas de los Distritos de Riego Año Agrícola 2015-2016; Edición: Mexico City, Mexico, 2017.

20. Romero, H.C.; Márquez, G.; Sánchez, R.; Fierros, E. Tendencias climáticas en el estado de Sinaloa. In Sinaloa Ante el Cambio Climático Global; Flores, M., Morán, E., Karam, C., Eds.; Universidad Autónoma de Sinaloa-INAPI: Culiacán, Mexico, 2014; pp. 77-106.

21. Lara, P.E.; Valdez, V.J.; Medina, T.S.; Martinez, R.R. Situación de la agricultura de Mayos y Mestizos del norte del Sinaloa, Mexico. Agric. Soc. Desarro. 2017, 14, 577-597.

22. Flores, L.; Arzola, J.; Ramírez, M.; Osorio, A. Global Climate Change Impacts in the Sinaloa State, Mexico. Cuad. Geogr. Rev. Colomb. Geogr. 2012, 21, 115-129. [CrossRef]

23. López, A.; Hernández, D. Cambio climático y agricultura: Una revisión de la literatura con énfasis en América Latina. Trimest. Econ. 2016, 83, 459-496. [CrossRef]

24. Google. (s.f.). Map of Sinaloa, Mexico in Google Maps. Available online: https://www.google.com.co/ maps /@4.6315748,-74.0699088,11.79z?hl=en (accessed on 3 October 2018).

25. Mejìa, J. Tolerancia y Aversión al Riesgo. 2015. Available online: https://www.21tradingcoach.com/ es/formaci\%C3\%B3n-gratuita/an\%C3\%A1lisis-cuantitativo/128-tolerancia-y-aversi\%C3\%B3n-al-riesgo (accessed on 7 September 2018).

26. Pindyck, R.; Rubinfeld, D. Microeconomía, 7th ed.; Prentice Hall: Madrid, Spain, 2009; Chapter 5; pp. $149-165$.

27. Andersen, S.; Harrison, G.; Lau, M.; Rutstrom, E. Eliciting Risk and Time Preferences. Econometrica 2008, 76, 583-618. [CrossRef]

28. Holt, C.A.; Laury, S.K. Risk Aversion and Incentive Effects. Am. Econ. Rev. 2002, 92, 1644-1655. [CrossRef]

29. Gonzalez, J.; Arora, P.; Podesta, G. Using Insights from Prospect Theory to Enhance Sustainable Decision Making by Agribusinesses in Argentina. Sustainability 2018, 10, 2693. [CrossRef]

30. Tian, D.; Yang, B.; Chen, J.; Zhao, Y. A multi-experts and multi-criteria risk assessment model for safety risks in oil and gas industry integrating risk attitudes. Knowl.-Based Syst. 2018, 156, 62-73. [CrossRef]

31. Aliaga, J.; Oropeza, A. Análisis experimental de la Curva de Laffer y la evasión fiscal en Bolivia. Rev. Latinoam. Desarro. Econ. 2015, 24, 134-141.

32. Menkhoff, L.; Sakha, S. Estimating Risky Behavior with Multiple-Item Risk Measures: An Empirical Examination. DIW Discussion. 2016, p. 1608. Available online: https:/ /www.econstor.eu/handle/10419/146901 (accessed on 22 August 2018).

33. Hu, J.; Bansal, M.; Mehrotra, S. Robust decision making using a general utility set. Eur. J. Oper. Res. 2018, 269, 699-714. [CrossRef]

34. Liontakis, A.; Tzouramani, I. Economic Sustainability of Organic Aloe Vera Farming in Greece under Risk and Uncertainty. Sustainability 2016, 8, 338. [CrossRef]

35. Jin, X.; Hossan, S.; Asgari, H.; Shams, K. Incorporating attitudinal aspects in roadway pricing analysis. Transp. Policy 2018, 62, 38-47. [CrossRef]

36. Avalos, E. Uncertainty: Lotteries and Risk; Munich Personal REPEC; Centro de Investigaciones Económicas: Lima, Peru, 2011.

37. Capinski, M.J.; Kopp, E.; Ski, M.J.C. Portfolio Theory and Risk Management; Cambridge University Press: Cambridge, UK, 2014. 
38. Bardhan, D.; Dabas, Y.P.S.; Tewari, S.K.; Kumar, A. An assessment of risk attitude of dairy farmers in Uttaranchal (India). In Proceedings of the International Association of Agricultural Economists Conference, Gold Coast, Australia, 12-18 August 2006; pp. 12-18.

39. He, P. Self-assessed risk attitudes predict behavior under risk? Evidence from a field study in China. Econ. Lett. 2018, 172, 107-109. [CrossRef]

40. Fausti, S. Factors Influencing Cash Marketing Decisions for Fed Cattle. Staff. Department of Economics, South Dakota State University, Brookings, 1998. paper No. 98-1. Available online: https://openprairie. sdstate.edu/cgi/viewcontent.cgi?article=1134\&context=econ_staffpaper (accessed on 1 July 2018).

41. Allub, L. Aversión al riesgo y adopción de innovaciones tecnológicas en pequeños productores rurales de zonas áridas: Un enfoque causal. Estudios Sociológicos 2001, 19, 467-493. Available online: http:/ /www.jstor. org.ezproxy.unal.edu.co/stable/40420990 (accessed on 18 July 2018).

42. Olbrich, R.; Quaas, M.; Baumgärtner, S. Risk preferences under multiple risk conditions—Survey evidence from semi-arid rangelands I. Introduction. In Proceedings of the 8th International Conference of the European Society for Ecological Economics, Transformation, Innovation and Adaptation for Sustainability, Ljubljana, Slovenia, 29 June-2 July 2009; pp. 1-15.

43. Binswanger, H. Attitudes towards Risk: Experimental Measurement in Rural India. Am. J. Agric. Econ. 1980, 62, 395-407. [CrossRef]

44. Brick, K.; Visser, M.; Burns, J. Risk Aversion: Experimental Evidence from South African Fishing Communities. Am. J. Agric. Econ. 2012, 94, 133-152. [CrossRef]

45. Rojas, R. Guía para Realizar Investigaciones Sociales, 40th ed.; Plaza y Valdez S.A.: Mexico City, Mexico, 2005; p. 237.

46. Gomera, A.; Villamandos, F.; Vaquero, M. Construction of indicators of environmental beliefs from the NEP scale. Acción. Psicol. 2013, 10, 149-160. [CrossRef]

47. Moyano, E.; Cornejo, F.A.; Gallardo, I. Creencias y Conductas Ambientales, Liberalismo Económico y Felicidad. Acta Colomb. Psicol. 2015, 14, 69-77. Available online: https://editorial.ucatolica.edu.co/ ojsucatolica/revistas_ucatolica/index.php/acta-colombiana-psicologia/article/view/346 (accessed on 3 September 2018).

48. Harpe, S.E. How to analyze Likert and other rating scale data. Sciencedirect 2015, 7, 836-850. [CrossRef]

49. Vozmediano, S.L.; Guillén, C. Escala Nuevo Paradigma Ecológico: Propiedades psicométricas con una muestra española obtenida a través de Internet. Medio Ambient. Comport. Hum. 2005, 6, 37-49.

50. Ghaffar, A. Climate change and associated spatial heterogeneity of Pakistan: Empirical evidence using multidisciplinary approach. Sci. Total Environ. 2018, 634, 95-108. [CrossRef]

51. Intergovernmental Panel on Climate Change (IPCC). Climate Change; IPCC: Geneva, Switzerland, 2014.

52. Gori, A.; Brito, B.; Ruiz, J. Climate Change and Agriculture: Do Environmental Preservation and Ecosystem Services Matter? Ecol. Econ. 2018, 152, 27-39. [CrossRef]

53. Greenpeace. La Agricultura Mexicana y el Cambio; Greenpeace: Mexico City, Mexico, 2010; Volume 1, pp. 4-11.

54. Morales-Casco, L.A.; Zúniga-González, C. A Impactos del cambio climático en la agricultura y seguridad alimentaria. Rev. Iberoam. Bioecon. Cambio Clim. 2016, 2, 269. [CrossRef]

55. Fadhelab, S.; Rico, M.A.; Hana, D. Sensitivity of peak flow to the change of rainfall temporal pattern due to warmer climate. J. Hydrol. 2018, 560, 546-559. [CrossRef]

56. Araus, J.; Slafer, G.; Royo, C.; Serret, M. Breeding for yield potential and stress adaptation in cereals. Crit. Rev. Plant Sci. 2008, 27, 377-412. [CrossRef]

57. Stocker, T.F.; Qin, D.; Plattner, G.-K.; Tignor, M.M.B.; Allen, S.K.; Boschung, J.; Nauels, A.; Xia, Y.; Bex, V.; Midgley, P.M. Cambio Climático. Bases Físicas. 2013. Available online: https://www.ipcc.ch/pdf/ assessment-report/ar5/wg1/WG1AR5_SummaryVolume_FINAL_SPANISH.pdf (accessed on 21 September 2018).

58. Quiroga, A. Impactos del Cambio Climático en la Incidencia de Plagas y Enfermedades de los Cultivos. 2013. Available online: https:/ / www.croplifela.org/es/actualidad/articulos/197-impactos-del-cambio-climaticoen-la-incidencia-de-plagas-y-enfermedades-de-los-cultivos (accessed on 12 September 2017).

59. Vásquez, L. Cambio Climático, Incidencia de Plagas y Prácticas Agroecológicas Resilientes; Instituto Nacional de Ciencias Agrícolas (INCA): La Habana, Cuba, 2011; 242p.

60. Galindo, L.M. La Economía del Cambio Climático en Mexico. Semarnat 2013, 53, 1689-1699. [CrossRef] 
61. Drichoutis, A.; Lusk, J. What Can Multiple Price Lists Really Tell Us about Risk Preferences? Munich Personal RePEc Archive. MPRA Paper 2012. Available online: http://www2.aueb.gr/conferences/Crete2013/ papers/Drichoutis.pdf (accessed on 10 August 2018).

62. March, C.; Ziegelmeyer, A.; Greiner, B.; Cyranek, R. Monetary Incentives in Large-Scale Experiments: A Case Study of Risk Aversion; Technische Munchen University: Munich, Germany, 2014.

63. Scrogin, D. Risk preferences over simple and compound public lotteries. Econ. Lett. 2018, 170, 85-87. [CrossRef]

64. Trujillo, J.C.; Escobar, J.L.; Iglesias, W.J. Medición de las actitudes hacia el riesgo en los pequeños productores de piña de Santander, Colombia. Cuad. Desarro. Rural 2012, 9, 239-255.

65. Galarza, F. Choices under Risk in Rural Peru; University of Wisconsin: Madison, WI, USA, 2009.

66. Doss, C.; Meinzen-Dick, R.; Quisumbing, A.; Theis, S. Women in agriculture: Four myths. Glob. Food Secur. 2018, 16, 69-74. [CrossRef] [PubMed]

67. Fisher, M.; Carr, E.R. The influence of gendered roles and responsibilities on the adoption of technologies that mitigate drought risk: The case of drought-tolerant maize seed in eastern Uganda. Glob.Environ. Chang. 2015, 35, 82-92. [CrossRef]

68. Takeshima, H.; Yamauchi, F. Risks and farmers' investment in productive assets in Nigeria. Agric. Econ. 2012, 43, 143-153. [CrossRef]

69. De Pinto, A.; Robertson, R.D.; Darko, O.B. Adoption of climate change mitigation practices by risk-averse farmers in the Ashanti Region, Ghana. Ecol. Econ. 2013, 86, 47-54. [CrossRef]

70. Dörschner, T.; Musshoff, O. Cost-oriented evaluation of ecosystem services under consideration of income risks and risk attitudes of farmers. Environ. Manag. 2013, 127, 249-254. [CrossRef] [PubMed]

71. Pomareda, C. Políticas Públicas para la Adaptación a la Variabilidad del Clima y al Cambio Climático. In Políticas y Sistemas de Incentivos para el Fomento y Adopción de Buenas Prácticas Agrícolas Como una Medida de Adaptación al Cambio Climático en América Centra; Sepúlveda-L., L.C., Ibrahim, M., Eds.; Centro Agronómico Tropical de Investigación y Enseñanza (CATIE): Turrialba, Costa Rica, 2009.

72. Brown, P.; Daigneault, A.; Tjernström, E.; Zou, W. Natural disasters, social protection, and risk perceptions. World Dev. 2018, 104, 310-325. [CrossRef] [PubMed]

73. Reyna, C.; Bressán, E.; Mola, D.; Belaus, A.; Ortiz, M. Validating the structure of the New Ecological Paradigm scale among Argentine citizens trough different approaches. Pensam. Psicol. 2018, 16, 107-118. [CrossRef]

(C) 2018 by the authors. Licensee MDPI, Basel, Switzerland. This article is an open access article distributed under the terms and conditions of the Creative Commons Attribution (CC BY) license (http://creativecommons.org/licenses/by/4.0/). 